\title{
Comparison of immunodiffusion and enzyme linked immunosorbent assay for antibodies to four Aspergillus species
}

\author{
J H FROUDIST, G B HARNETT, R McALEER Medical Mycology Laboratory and the Virology \\ Laboratory, Combined Microbiology Service, State Health Laboratories, Perth, Western Australia
}

SUMMARY Antigenic extracts were prepared from Aspergillus fumigatus, $A$ niger, $A$ flavus and $A$ terreus for use in enzyme linked immunosorbent assay (ELISA) and immunodiffusion (ID) tests for Aspergillus antibodies to determine whether the use of antigenic extracts from species other than $A$ fumigatus increased the sensitivity of the ELISA. ELISA titres correlated well with positive ID tests. Patient titres by ELISA were significantly higher than control titres for all species. Patient titres to $A$ niger were also significantly higher than titres to the other species. Total number of ID bands to $A$ fumigatus correlated significantly with anti- $A$ fumigatus ELISA titres. It is concluded that the use of antigenic extracts from species other than $A$ fumigatus improves the sensitivity of the ELISA.

Members of the genus Aspergillus may be implicated in various clinical diseases and this has been well described in previous studies. ${ }^{12}$ Serodiagnostic methods for detection of antibody have become increasingly important in the diagnosis of aspergillosis, and the most widely used of these is the immunodiffusion (ID) test, due to its simplicity and reproducibility. Its major disadvantages are lack of sensitivity and the length of time necessary to obtain a result. Several researchers have suggested that an enzyme linked immunosorbent assay (ELISA) should be used instead because of its sensitivity, rapidity, and direct measurement of antibody without reliance on "secondary phenomena."

It has been shown that detection of antibody to Aspergillus is improved by the use of antigenic extracts from a battery of Aspergillus species. ${ }^{7-9}$ All sera received for Aspergillus serology by the medical mycology branch of the Western Australian State Health Laboratory Services are routinely tested by ID against extracts from four species: $A$ fumigatus (two strains), $A$ niger, $A$ flavus and $A$ terreus. A fumigatus is the species responsible for most cases of Aspergillusrelated disease, and at the time of writing all reports found dealing with ELISA assays for antibody to Aspergillus in man dealt only with this species. This study compared ELISA and ID assays for antibody to four Aspergillus species to determine whether the use of antigenic extracts from species other than $A$ fumigatus increased the sensitivity of the ELISA. Sera from patients with known or suspected Aspergillus-

Accepted for publication 7 June 1989 related disease caused by different Aspergillus species were compared with those of normal controls.

\section{Material and methods}

Strains of $A$ fumigatus NCPF 2140 , NCPF 2109, $A$ niger NCPF 2022, $A$ flavus NCPF 2008, and $A$ terreus NCPF 2026 were used. Antigens were prepared by mechanical disruption of mycelial mats. Cultures were grown for seven days at room temperature in $250 \mathrm{ml}$ of $2 \%$ glucose, $1 \%$ peptone broth with $5 \%$ chloramphenicol (GPB) on a magnetic stirrer. These cultures were then inoculated into a further three litres of GPB and incubated for another seven days, then harvested on to gauze, washed with distilled water, dried, weighed, and stored at $-20^{\circ} \mathrm{C}$. A $50 \% \mathrm{w} / \mathrm{v}$ suspension of the mycelium was made in distilled water and disrupted for two minutes in a Waring Blender (Model 31 BL 44, Dynamics Corporation of America, New Hartford, Connecticut, USA). Thirty $\mathrm{ml}$ aliquots of the macerated material were further disrupted for four minutes in a Braun MSK Cell Homogeniser (Model 853030, Braun Instruments, San Francisco California, USA) while cooled by liquid carbon dioxide. The resulting homogenate was centrifuged at $10000 \times g$ for $\mathbf{1 0}$ minutes to remove gross debris. The supernate was frozen overnight, thawed, and centrifuged at $30000 \times \mathrm{g}$ for one hour at $5^{\circ} \mathrm{C}$. The supernate was dialysed against distilled water overnight at $5^{\circ} \mathrm{C}$, then against polyethylene glycol 2000 at $5^{\circ} \mathrm{C}$ to about $20 \%$ of the initial volume. It was then frozen overnight, thawed, and centrifuged at $30000 \times g$ for one hour at $5^{\circ} \mathrm{C}$. The resulting supernate was freeze-dried under 
vacuum in small aliquots and reconstituted as required to $20 \mathrm{mg}$ dry weight $/ \mathrm{ml}$ of phosphate buffered saline, $\mathrm{pH} 7 \cdot 0$, for use in ID tests. The $A$ fumigatus ID antigen was a composite of extracts from the two strains, in equal mixture by weight.

\section{CONTROL ANTISERA FOR ID TESTS}

Control antisera were raised in New Zealand white rabbits using a regimen of subcutaneous inoculations of antigen in Freund's incomplete adjuvant and intravenous inoculations of saline preparations. Inoculum strength was $30 \mathrm{mg} / \mathrm{ml}$. Rabbit sera were tested by ID against homologous antigens at three week intervals to assess success of immunisation.

\section{PATIENT SERA}

ID positive sera from 17 patients with different clinical forms of aspergillosis were tested by ELISA (table 1). Where possible, microscopical examination and culture of sputum was performed to check for evidence of aspergillosis. All sera were stored at $-20^{\circ} \mathrm{C}$ until tested by ELISA. Sex ratio was 10 men to seven women.

\section{CONTROL SERA}

Nineteen control sera were selected from patients with no clinical evidence of respiratory disease and age and sex matched as closely as possible to the patient sera.

\section{IMMUNODIFFUSION}

Agarose gel slides for ID were prepared and the slides washed, dried, and stained essentially by the method of Philpot et al, ${ }^{10}$ with minor modifications. A citrate buffer was used to eliminate possible false positive results due to $\mathrm{C}$-substance. Well sizes used were: $11 \mathrm{~mm}$ for patient serum; $5 \mathrm{~mm}$ and $3 \mathrm{~mm}$ for antigen; and $6 \mathrm{~mm}$ for control rabbit antiserum. Interwell distance was $6 \mathrm{~mm}$. ID was allowed to proceed for 72 hours with the gels stood in Borax-saline overnight, were dried, and stained by Coomassie blue. The relatively large patient well was used to minimise the chance of excess antigen. The smaller of the two

Table 1 ELISA and ID results from 17 patient sera

\begin{tabular}{|c|c|c|c|c|c|c|c|c|c|c|c|}
\hline \multirow{2}{*}{$\begin{array}{l}\text { Case } \\
\text { No }\end{array}$} & \multicolumn{2}{|c|}{ A fumigatus } & \multicolumn{2}{|c|}{ A niger } & \multicolumn{2}{|c|}{ A flavus } & \multicolumn{2}{|c|}{ A terreus } & \multirow{2}{*}{$\begin{array}{l}\text { Sputum } \\
\text { microscopy }\end{array}$} & \multirow{2}{*}{$\begin{array}{l}\text { Sputum } \\
\text { culture }\end{array}$} & \multirow{2}{*}{$\begin{array}{l}\text { History/ } \\
\text { diagnosis }\end{array}$} \\
\hline & $I D$ & $E L I S A$ & $I D$ & $E L I S A$ & $I D$ & $E L I S A$ & $I D$ & ELISA & & & \\
\hline 1 & $3 P$ & $1 / 10240$ & $2 I$ & $1 / 20480$ & $3 I$ & $1 / 10240$ & $3 I$ & $1 / 20480$ & + & A terreus & $\begin{array}{l}\text { Allergic bronchopulmonar } \\
\text { aspergillosis (ABPA) }\end{array}$ \\
\hline 2 & $5 I$ & $1 / 5120$ & $1 N$ & $1 / 20480$ & $3 \mathbf{P}$ & $1 / 10240$ & 4P & $1 / 10240$ & + & $\begin{array}{l}\text { A fumigatus } \\
\text { A niger } \\
\text { A flavus } \\
\text { A terreus }\end{array}$ & ABPA \\
\hline 3 & $3 I$ & $1 / 10240$ & 1I & $1 / 10240$ & $3 \mathbf{P}$ & $1 / 5120$ & 3P & $1 / 5120$ & - & $\begin{array}{l}\text { Non-sporing } \\
\text { fungus }\end{array}$ & ABPA \\
\hline 4 & 6I & $1 / 20480$ & $2 \mathrm{I}$ & $1 / 20480$ & $\begin{array}{l}1 \mathrm{I} \\
1 \mathrm{~N}\end{array}$ & $1 / 20480$ & $1 \mathbf{P}$ & $1 / 10240$ & + & $\begin{array}{l}\text { A fumigatus, } \\
\text { A niger, } \\
\text { A terreus }\end{array}$ & Long standing ABPA \\
\hline 5 & 2I & $1 / 1280$ & - & $1 / 5120$ & 3I & $1 / 10240$ & ND & ND & + & A fumigatus & ABPA \\
\hline 6 & 7P & $1 / 20480$ & - & $1 / 640$ & - & $1 / 640$ & - & $1 / 1280$ & + & A fumigatus & $\begin{array}{l}\text { Chest infection, allergic } \\
\text { rhinitis, eosinophilia, } \\
\text { ? ABPA }\end{array}$ \\
\hline 7 & 11 & $1 / 5120$ & 11 & $1 / 40960$ & $1 P$ & $1 / 10240$ & $1 \mathrm{I}$ & $1 / 5120$ & + & A terreus & $\begin{array}{l}\text { Asthma, on steroids, } \\
\text { ? ABPA }\end{array}$ \\
\hline 8 & - & $<1 / 80$ & $1 \mathrm{I}$ & $1 / 20480$ & $\begin{array}{l}11 \\
1 N\end{array}$ & $1 / 10240$ & ND & ND & - & $\begin{array}{l}\text { Aspergillus } \\
\text { species }\end{array}$ & $\begin{array}{l}\text { Hayfever, atypical } \\
\text { shadows? ABPA }\end{array}$ \\
\hline 9 & 11 & $1 / 640$ & 11 & $1 / 20480$ & $2 I$ & $1 / 10240$ & ND & ND & + & $\begin{array}{l}\text { A fumigatus } \\
\text { A niger }\end{array}$ & Eosinophilia,? ABPA \\
\hline 10 & $4 I$ & $1 / 20480$ & $2 \mathbf{P}$ & $1 / 40960$ & $3 \mathbf{P}$ & $1 / 20480$ & $1 \mathbf{P}$ & $1 / 10240$ & + & $\begin{array}{l}\text { A fumigatus } \\
\text { A niger }\end{array}$ & $\begin{array}{l}\text { Asthma many years, } \\
\text { ? ABPA }\end{array}$ \\
\hline 11 & $2 I$ & $1 / 40960$ & $1 \mathrm{II}$ & $1 / 20480$ & $\begin{array}{l}1 \mathrm{I} \\
1 \mathbf{N}\end{array}$ & $1 / 20480$ & ND & ND & - & A niger & $\begin{array}{l}\text { Aspergilloma } \\
\text { and ABPA }\end{array}$ \\
\hline 12 & $2 I$ & $1 / 5120$ & $2 I$ & $1 / 20480$ & $2 I$ & $1 / 10240$ & 11 & $1 / 2560$ & + & A terreus & Aspergilloma \\
\hline 13 & - & $1 / 5120$ & 11 & $1 / 40960$ & 11 I & $1 / 10240$ & ND & ND & + & A niger & Aspergilloma \\
\hline $\begin{array}{l}14 \\
15\end{array}$ & - & $\begin{array}{l}1 / 1280 \\
1 / 320\end{array}$ & $2 I$ & $\begin{array}{l}1 / 20480 \\
1 / 5120\end{array}$ & $\begin{array}{l}- \\
1 \mathrm{II} \\
1 \mathbf{N}\end{array}$ & $\begin{array}{l}1 / 10240 \\
1 / 2560\end{array}$ & $\begin{array}{l}\text { ND } \\
\text { ND }\end{array}$ & $\begin{array}{l}\text { ND } \\
\text { ND }\end{array}$ & $\stackrel{+}{\mathbf{N A}}$ & $\begin{array}{l}\text { A niger } \\
\text { NA }\end{array}$ & $\begin{array}{l}\text { Aspergilloma } \\
\text { ? aspergilloma }\end{array}$ \\
\hline 16 & - & $1 / 160$ & $1 I$ & $1 / 5120$ & - & $1 / 640$ & - & $1 / 160$ & NA & NA & $\begin{array}{l}\text { Cavity right lung } \\
\text { ? aspergilloma }\end{array}$ \\
\hline 17 & $1 I$ & $1 / 5120$ & - & $1 / 10240$ & $\begin{array}{l}11 \\
1 \mathrm{~N}\end{array}$ & $1 / 10240$ & 11 & $1 / 2560$ & - & A terreus & $\begin{array}{l}\text { Pulmonary } \\
\text { aspergillosis two } \\
\text { years ago, patches } \\
\text { on chest } x \text { ray }\end{array}$ \\
\hline
\end{tabular}

Sputum microscopy recorded as positive if fungal mycelium present. Bands of: $\mathrm{I}=$ identity; $\mathrm{P}=$ partial identity; $\mathrm{N}=$ non-identity 
antigen wells was added to further increase this well size differential, and to maximise detection of low patient antibody titres.

\section{PLATES FOR ELISA}

Polystyrene microtitration plates (Kayline TV 96 Plymton, South Australia) were immersed in alcohol for 15 minutes, washed for 15 minutes in detergent (Haemo-sol, Baltimore, Maryland, USA), rinsed well in deionised water, and dried. The plates were coated with $100 \mu \mathrm{l} /$ well of appropriate antigen diluted to 0.25 $\mathrm{mg} / \mathrm{ml}$ in $0.05 \mathrm{M}$ carbonate buffer, $\mathrm{pH} 9.6$, by incubation at $37^{\circ} \mathrm{C}$ for two hours, then at $4^{\circ} \mathrm{C}$ for about 18 hours. The antigen concentrations were predetermined by chequerboard titration against known positive and negative human precipitating sera.

\section{CONJUGATE}

Rabbit antiserum to human IgG was purified by affinity chromatography. It was then coupled to alkaline phosphatase (Sigma 104-105, Missouri, USA) in PBS, pH 7.3, at an alkaline phosphatase protein ratio of $3: 1$ with $0.2 \%$ glutaraldehyde (Ladd Research Industries, Burlington Vermont, USA) which had been previously treated with solid barium carbonate to reduce acidity. After conjugation had proceeded for three hours at room temperature alkaline phosphatase antibody complexes were separated by fractionation on a column of Sephadex G200 (Pharmacia, Uppsala, Sweden) in $0.2 \mathrm{M}$ TRIS-HCl buffer, $\mathrm{pH} 8.0$, and stored at $4^{\circ} \mathrm{C}$ with $2 \%$ fetal calf serum, and $0.08 \%$ sodium azide was added.

\section{ELISA METHOD}

Plates coated with antigen were given two five minute washes with $0.05 \%$ Tween 20 in $0.9 \%$ sodium chloride, and two-fold dilutions (1/10 - 1/20480) of patient and control sera in $100 \mu \mathrm{l}$ volumes were made in the plates in Tween 20-sodium chloride with $20 \%$ fetal calf serum added (TW-FCS). Sera which did not reach an end-point in this titration series were titrated further. Plates were then incubated for two hours at $37^{\circ} \mathrm{C}$, washed twice in Tween 20 -sodium chloride, and $100 \mu \mathrm{l}$ of conjugate diluted in TW-FCS at a predetermined concentration $(1 / 160)$ was added to each well.

After two hours of incubation at $37^{\circ} \mathrm{C}$ plates were again washed twice in Tween 20 -sodium chloride and $100 \mu \mathrm{l}$ of substrate $(1 \mathrm{mg}$ p-nitrophenyl phosphate, disodium (Sigma Chemical Co St Louis, Missouri, USA)/one $\mathrm{ml} 1 \mathrm{M}$ diethanolamine buffer $\mathrm{pH} 9.7$ with $0.5 \mathrm{mM} \mathrm{MgCl}$ ) added to each well. After 20 minutes of incubation at $37^{\circ} \mathrm{C}, 50 \mu \mathrm{l}$ of $2 \mathrm{M} \mathrm{NaOH} /$ well was added to stop the reaction and absorbance of the reaction product determined in a spectrophotometer (Beckman DG-B, Fullerton, California, USA) at $405 \mathrm{~nm}$. Cut-off values were determined from results of a known positive and negative serum included in each batch of tests. Titres of less than 1/80 were not scored.

\section{Results}

\section{TEST REPRODUCIBILITY}

Both ID and ELISA tests showed a high degree of reproducibility. The ranking of sera by ELISA was very consistent, while actual titres were either steady or drifted by no more than one two-fold dilution. Control sera were included in each run for comparison with patient sera and with previous results.

Table 2 ELISA and ID results from 19 age and sex matched control sera

\begin{tabular}{|c|c|c|c|c|c|c|c|c|}
\hline \multirow[b]{2}{*}{ Control } & \multicolumn{2}{|c|}{ A fumigatus } & \multicolumn{2}{|c|}{ A niger } & \multicolumn{2}{|c|}{ A flavus } & \multicolumn{2}{|c|}{ A terreus } \\
\hline & $I D$ & $E L I S A$ & $I D$ & $E L I S A$ & $I D$ & $E L I S A$ & $I D$ & $E L I S A$ \\
\hline 1 & - & $1 / 160$ & - & $1 / 160$ & - & $1 / 80$ & - & $<1 / 80$ \\
\hline 2 & - & $1 / 640$ & - & $1 / 160$ & - & $1 / 160$ & - & $1 / 320$ \\
\hline 3 & - & $1 / 160$ & - & $1 / 160$ & - & $<1 / 80$ & - & $1 / 80$ \\
\hline 4 & - & $1 / 320$ & - & $<1 / 80$ & - & $1 / 160$ & - & $1 / 80$ \\
\hline 5 & - & $1 / 160$ & - & $1 / 320$ & - & $1 / 160$ & - & $1 / 640$ \\
\hline 6 & - & $1 / 320$ & - & $1 / 1280$ & - & $1 / 160$ & - & $1 / 160$ \\
\hline 7 & - & $1 / 160$ & - & $1 / 1280$ & - & $1 / 640$ & - & $1 / 160$ \\
\hline 8 & - & $1 / 640$ & - & $1 / 5120$ & - & $1 / 2560$ & - & $1 / 1280$ \\
\hline 9 & - & $1 / 80$ & - & $1 / 320$ & - & $1 / 320$ & - & $1 / 160$ \\
\hline 10 & - & $1 / 80$ & - & $1 / 160$ & - & $1 / 160$ & - & $<1 / 80$ \\
\hline 11 & - & $<1 / 80$ & - & $1 / 320$ & - & $1 / 160$ & - & $<1 / 80$ \\
\hline 12 & - & $1 / 80$ & - & $1 / 1280$ & - & $1 / 640$ & - & $<1 / 80$ \\
\hline 13 & - & $<1 / 80$ & - & $1 / 320$ & - & $1 / 80$ & - & ND \\
\hline 14 & - & $1 / 320$ & - & $1 / 1280$ & - & $1 / 320$ & - & ND \\
\hline 15 & - & $<1 / 80$ & - & $1 / 320$ & - & $1 / 640$ & - & ND \\
\hline 16 & - & $<1 / 80$ & - & $1 / 640$ & - & $1 / 320$ & - & ND \\
\hline 17 & - & $<1 / 80$ & - & $1 / 2560$ & trace & $1 / 2560$ & - & ND \\
\hline 18 & - & $<1 / 80$ & - & $1 / 80$ & - & $1 / 160$ & - & ND \\
\hline 19 & - & $<1 / 80$ & - & $1 / 2560$ & Ibid & $1 / 2560$ & - & ND \\
\hline
\end{tabular}

Ibid = one band of identity. 
Table 3 Overall mean ELISA titres

\begin{tabular}{lllll}
\hline & A fumigatus & A niger & A flavus & A terreus \\
\hline Patients & $1 / 8954$ & $1 / 19012$ & $1 / 10164$ & $1 / 6800$ \\
Controls & $1 / 193$ & $1 / 968$ & $1 / 627$ & $1 / 267$ \\
$\begin{array}{l}\text { Ratio patient to } \\
\begin{array}{c}\text { control mean } \\
\text { titres }\end{array}\end{array}$ & $46 / 1$ & $19 / 1$ & $16 / 1$ & $26 / 1$ \\
\hline
\end{tabular}

Note: titres of $<1 / 80$ given value of $1 / 40$ for purposes of calculation.

\section{ELISA TITRES AND ID RESULTS FROM PATIENTS}

Patient ELISA titres ranged from $<1 / 80$ to $1 / 40960$ (table 1). Precipitin bands produced by patient sera were characterised as either bands of identity, partial identity, or non-identity with control antisera. "It was only possible to test 10 of the 17 patient sera with
$A$ terreus antigen. Mean patient $A$ niger titres were significantly higher than patient titres to the other species (Wilcoxon test; p $<0.05$ ).

ELISA TITRES AND ID RESULTS FROM CONTROLS Control ELISA titres ranged from $1 / 80$ to $1 / 5120$ (table 2). Two control sera with $A$ flavus titres of 1/2560 were ID positive for $A$ flavus, while all other control sera were ID negative. Mean control $A$ niger and $A$ flavus titres were significantly higher than mean control titres to the other two species (Wilcoxon test; $\mathrm{p}<0.05)$.

\section{COMPARISON OF PATIENT AND CONTROL ELISA TITRES}

No sex differences were detected in either patient or

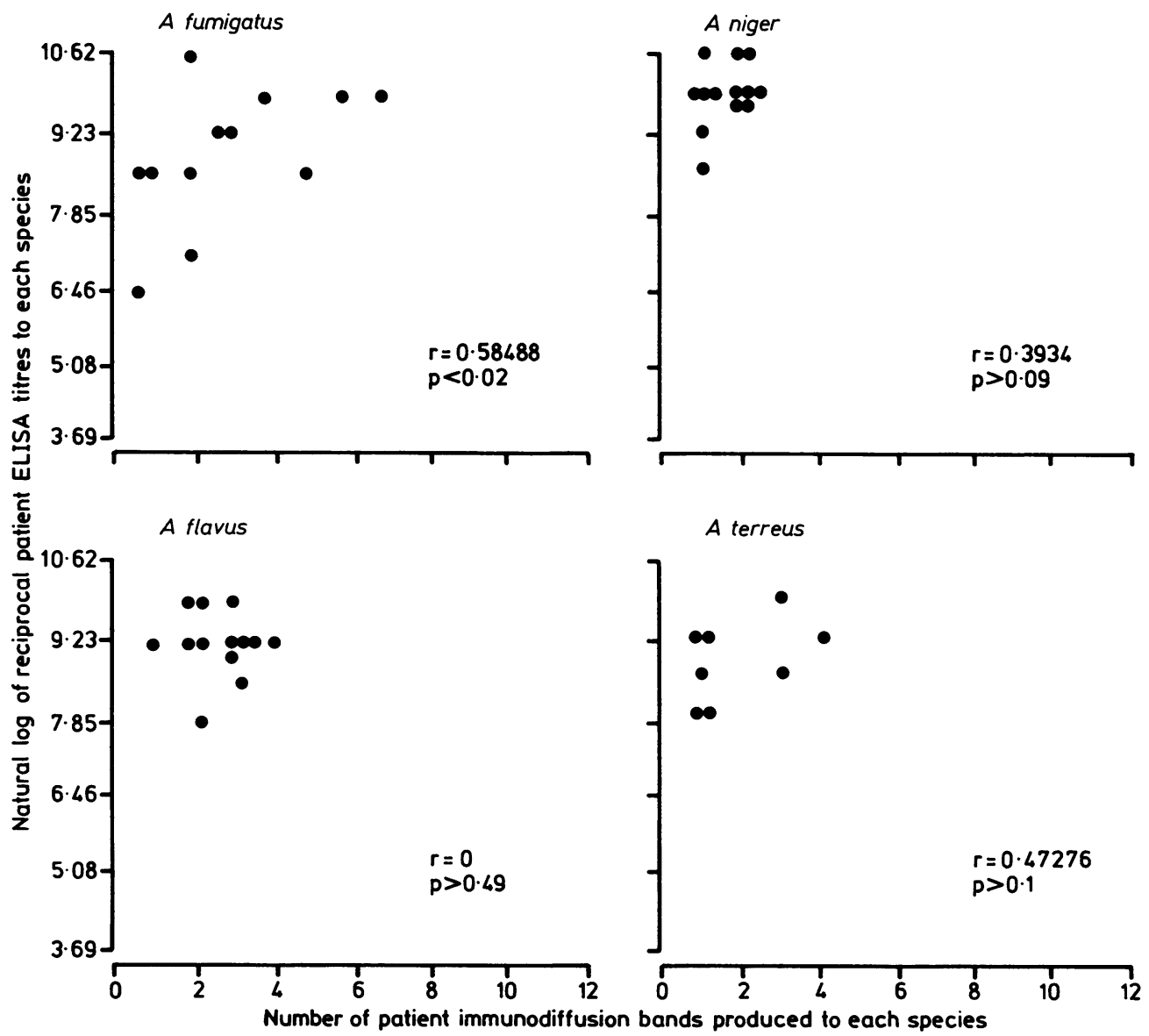

Fig 1 Number of patient immunodiffusion (ID) bands produced to each species compared with the natural logarithm of the reciprocal patient ELISA titre to each species. Number of ID bands to A fumigatus correlated significantly with anti-fumigatus ELISA titres (top left). No correlation between ID bands and ELISA titres for A niger (top right), A flavus (bottom left), and $A$ terreus (bottom right). 
control titres (Student's $t$ test; $p>0 \cdot 5$ ). Results for men and women were therefore combined for both patients and controls (table 3). Mean patient ELISA titres were significantly higher than control titres for all species (Wilcoxon test, $\mathrm{p}<0.01$ ). There were no significant differences between the respective ratios of patient titre to control titre for all species (Student's $t$ test; $p>0.05$ ).

\section{PATIENT ELISA TITRES WITH NEGATIVE ID}

When ID was negative, patient ELISA titres ranged from $<1 / 80$ to $1 / 10240$. In all cases when ID was negative for a particular species, there was a heterologous positive ID test for at least one other species.

PATIENT ELISA TITRES WITH POSITIVE ID

In all instances where ID was positive, ELISA titres were $1 / 640$ or higher. The nature of the bands produced (whether bands of identity, partial identity,
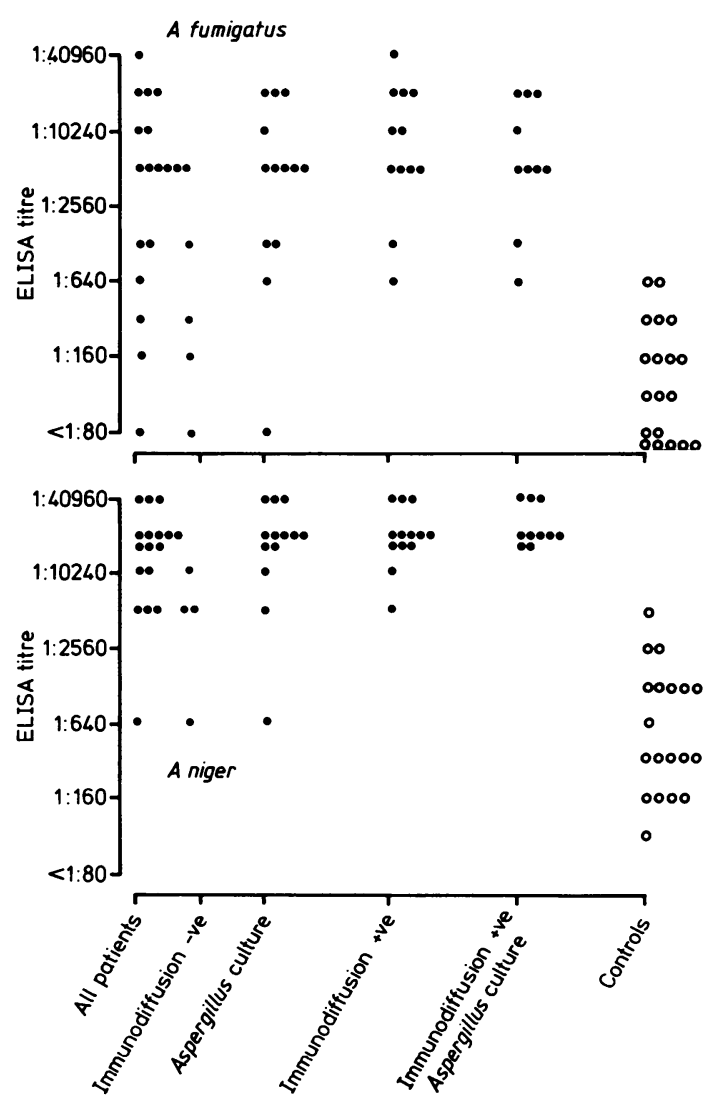

Fig 2 ELISA titre distributions for A fumigatus and $A$ niger. $\bigcirc$ = patients; $\bigcirc=$ controls; $I D+v e=I D$ positive; ID - ve $=I D$ negative. or non-identity) showed no obvious correlation with ELISA titres for any species. Fig 1 compares the number of ID bands produced by patient sera with the natural logarithm of the reciprocal ELISA titre to the same antigen. The number of ID bands to $A$ fumigatus correlated significantly with the anti-fumigatus ELISA titre. There was no correlation between number of ID bands and ELISA titres for $A$ niger, $A$ flavus, and $A$ terreus, respectively.

\section{ELISA TITRE DISTRIBUTION}

ELISA titres were plotted for:

(1) all patients; (2) patients with negative ID results;

(3) patients with an Aspergillus species cultured from sputum; (4) patients with positive ID results; (5) patients with positive ID plus positive culture for Aspergillus; (6) controls. These results are summarised in figs 2 and 3.

In only one case where an Aspergillus species was cultured was the anti-fumigatus titre lower than 1/640

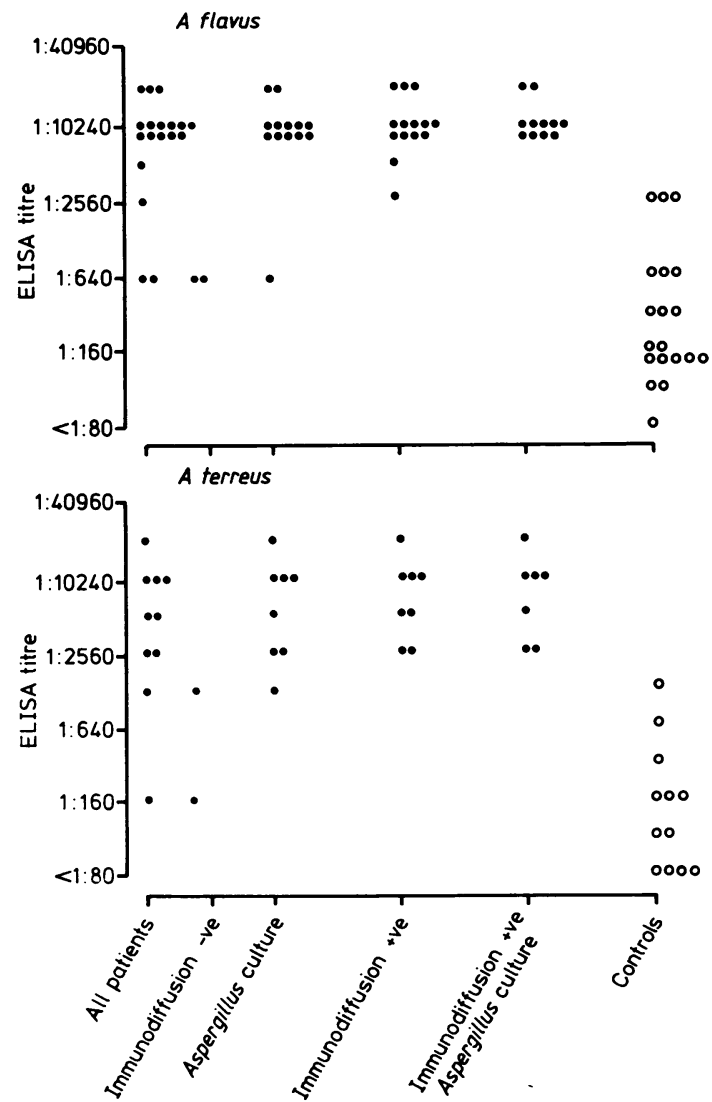

Fig 3 ELISA titre distributions for A flavus and A terreus. 0 patients; $\bigcirc=$ controls $; I D+v e=I D$ positive; $I D-v e=I D$ negative. 
(top, fig 2). This was case 8, also ID negative for $A$ fumigatus. This patient was ID positive for $A$ niger and $A$ flavus with correspondingly high ELISA titres. The Aspergillus species cultured was not one of the four species specifically tested for. No patients who were both ID positive and Aspergillus culture positive had an anti-fumigatus titre lower than $1 / 640$. The lowest anti- $A$ niger titre with an Aspergillus cultured from sputum was $1 / 640$ (bottom, fig 2). This was case 6 from whom $A$ fumigatus was grown from the sputum and who had an anti- $A$ fumigatus titre of $1 / 20480$. No patients who were both ID and Aspergillus culture positive had an anti- $A$ niger titre lower than 1/20 480 . The lowest anti- $A$ flavus titre with an Aspergillus species cultured from sputum was 1/640 (top, fig 3) (case 6). No patients who were both ID positive and Aspergillus culture positive had anti- $A$ flavus titres lower than $1 / 10240$. The lowest anti- $A$ terreus titre with an Aspergillus cultured was 1/1280 (bottom, figure 3). This was also case six. No patients who were both ID positive and Aspergillus culture positive) had anti- $A$ terreus titres lower than $1 / 2560$.

\section{ASSOCIATION BETWEEN ID AND SPECIES CULTURED}

In all cases where $A$ fumigatus, $A$ niger and $A$ terreus alone was cultured ID was positive for that particular species (none of the patients grew A flavus alone). The type of ID band produced bore no relation to species cultured.

\section{ASSOCIATION BETWEEN ELISA AND SPECIES CULTURED}

Mean patient titres for each species (where that species was cultured from sputum) were: A fumigatus $1 / 11413$; $A$ niger 1/26331; and $A$ terreus $1 / 8530 ; A$ flavus was cultured only once with a titre of $1 / 10240$. The mean patient $A$ niger titre (when $A$ niger was cultured) was significantly higher by the Wilcoxon test than the overall mean $A$ niger titre $(\mathrm{p}<0.05)$, and was also significantly higher than the mean patient titres to the other species when cultured $(\mathrm{p}<0.05)$.

\section{Discussion}

Overall, positive precipitin results correlated well with ELISA titres in our study. The correlation obtained between number of ID bands and ELISA titres for $A$ fumigatus agrees with the findings of Sepulveda $e t a l^{\beta}$ and Kauffman et al, ${ }^{6}$ who found a definite correlation between number of ID bands to $A$ fumigatus and reactivity in ELISA. Why there was no such correlation for the other three species remains uncertain, particularly as both ID and ELISA responses to these species were generally heightened when these species were cultured. These latter results may have been statistical aberrations due to the relatively small number of samples tested-for example, $A$ flavus was isolated from only one of the patients tested. The ratio of mean patient titre to mean control titre seemed to be higher for $A$ fumigatus and $A$ terreus than for the other two species, but this was not supported statistically due to the spread of the data.

ELISA titres were consistently high when Aspergillus was isolated from sputum. The cut-off point for likely ELISA titre significance (using a criterion of two titres higher than the highest respective control titre) varied among the different species, ranging from $1 / 2560$ for $A$ fumigatus to $1 / 20480$ for $A$ niger. It is important to bear in mind when making this sort of analysis, however, that a small percentage of patients may have raised antibody titres to Aspergillus with no evidence of disease..$^{1213}$

There is some degree of serological cross reaction among different Aspergillus species, indicating the presence of common antigenic determinants. ${ }^{14} 15$ This was reflected in both our ID and ELISA results where, even when only one Aspergillus species was isolated from sputum, in most cases ID was positive and ELISA titres were high for several species. The possibility of false negative culture can not be discounted, however, in at least some of these cases. Cross reactions were also irregular in distribution and may reflect anamnestic recall of antibody to other previously encountered Aspergillus species.

Patient ELISA titres to $A$ niger were significantlyo higher than titres to the other species, yet the rabbit? $A$ niger control antiserum and patient sera tested by our laboratory generally produce fewer ID bands to $A$ niger than to the other species. Control $A$ niger (and control $A$ flavus) titres were significantly higher than control titres for the other two species. The fact that $A$ niger was the most sensitive antigen in ELISA possibly reflected different behaviour by this antigen, or various components of it, in the two systems. This might be due to a physical phenomenon such as more efficient binding to the polystyrene plates. It is interesting that De Magaldi and Mackenzie, ${ }^{16}$ when testing hyperimmune rabbit antisera by ELISA for reactivity against antigens prepared from the same Aspergillus strains utilised in this study, also found a relatively higher optical density with $A$ niger. The reasons for this greater reactivity of $A$ niger NCPF 2022 remain unknown. Further testing, using extracts from several $\boldsymbol{A}$ niger strains compared with several strains of each of the other species is necessary to determine whether this behaviour is species or strain specific.

Several authors have found that there is no absolute correlation between tests such as ID, counterimmunoelectrophoresis, and ELISA, and this is undoubtedly due in part to the fact that they measure 
different physicochemical phenomena. ${ }^{1718}$ Kauffman et al showed that ELISA detected antibodies against non-precipitating antigenic components, in addition to the antibodies detected by ID. ${ }^{19}$ This and a later study ${ }^{20}$ also showed that precipitating antibodies in ID did not always correspond with IgG ELISA results. Further discrepancies have also been shown among IgG, IgA, and IgM ELISA titres, ${ }^{20}$ and even between IgG subclass antibodies. ${ }^{21}$ The nature of the antigens used in all these different approaches is vitally important, and a considerable amount of work has been done on the characterisation of antigenic components of Aspergillus species and on their relative clinical importance. ${ }^{22} 23$ It would be interesting to apply some of these approaches to the use of antigenic extracts from several Aspergillus species in ELISA and other sensitive tests.

It was unfortunate that sera from patients with invasive aspergillosis (especially when caused by species other than A fumigatus) were not available at the time of this study. A larger number of sera from patients with well defined clinical types of aspergillosis, caused by different Aspergillus species, needs to be examined before any firm conclusions can be drawn about ELISA titres and disease type. It was evident, however, that some patients did produce significant ELISA titres to antigenic extracts from species other than $A$ fumigatus in the absence of significant $A$ fumigatus ELISA titres. It is clear that in any investigation of immune response to Aspergillus, even when using sensitive tests such as ELISA, assay sensitivity may be significantly improved by using antigenic extracts prepared from a range of Aspergillus species.

\section{References}

1 Bardana EJ, Gerber JD, Craig S, Cianciulli FD. The general and specific humoral immune response to pulmonary aspergillosis. Am Rev Resp Dis 1975;112:799-805.

2 McCarthy DS, Pepys J. Allergic broncho-pulmonary aspergillosis. Clin Allergy 1971;1:261-86.

3 Sepulveda R, Longbottom JL, Pepys J. Enzyme-linked immunosorbent assay (ELISA) for IgG and IgE antibodies to protein and polysaccharide antigens of Aspergillus fumigatus. Clin Allergy 1979;9:359-71.

4 Shale DJ, Faux JA. The evaluation of a quantitative enzymelinked immunosorbent assay (ELISA) for anti-Aspergillus fumigatus IgG. J. Immunol Methods 1985;7:197-205.

5 Richardson MD, Stubbins JM, Warnock DW. Rapid enzymelinked immunosorbent assay (ELISA) for Aspergillus fumigatus antibodies. J Clin Pathol 1982;35:1134-7.

6 Kauffman HF, Beaumont F, Meurs H. Comparison of antibody measurement against Aspergillus fumigatus by means of double-diffusion and enzyme-linked immunosorbent assay (ELISA). J Allergy Clin Immunol 1983;72:255-61.

7 Froudist JH, McAleer R, Cherian G. Serology for the detection of antibody to Aspergillus: use of extracts from four species. Aust $J$ Med Lab Sci 1986;7:57-60.
8 Gold JWM, Fisher B, Yu B, Chein N, Armstrong D. Diagnosis of invasive aspergillosis by passive hemagglutination assay of antibody. J Infect Dis 1980;142:87-94.

9 Galant SP, Rucker RW, Groncy CE, Wells ID, Novey HS. Incidence of serum antibodies to several Aspergillus species and to Candida albicans in cystic fibrosis. Am Rev Respir Dis 1976;114:325-31.

10 Philpot CM, Mackenzie DWR. Detection of antibodies to Aspergillus fumigatus in agar gel with different antigens and immunodiffusion patterns. J Biol Stand 1976;4:73-9.

11 Crowle AJ. Immunodiffusion. Academic Press, London 1973; 257-70.

12 Schonheyder H, Andersen P. IgG antibodies to purified Aspergillus fumigatus antigens determined by enzyme-linked immunosorbent assay. Int Arch Allergy Appl Immunol 1984;74:262-9.

13 Dewair M, Baur X. Radioallergosorbent Test (RAST) for measurement of IgG antibodies to Aspergillus fumigatus in sera of patients with different lung diseases. $J$ Immunol Methods 1984;75:117-28.

$14 \mathrm{Kim}$ SJ, Chaparas SD. Characterisation of antigens from Aspergillus fumigatus. III. Comparison of antigenic relationships of clinically important aspergilli. Am Rev Respir Dis 1979;120:303.

15 Chaparas SD, Kaufman L, Kim SJ, McLaughlin DW. Characterisation of antigens from Aspergillus fumigatus. V. Reactivity in immunodiffusion tests with serums from patients with aspergillosis caused by Aspergillus flavus, $\mathrm{A}$ niger, and $\mathbf{A}$ fumigatus. Am Rev Respir Dis 1980;122:647-50.

16 De Magaldi SW, Mackenzie DWR. Specificity of antigens from pathogenic Aspergillus species I. Studies with ELISA and Immunofluorescence. J Med Vet Mycol 1984;22:381-94.

17 Khan ZU, Richardson MD, Crutcher DL, Warnock DW. Use of Aspergillus fumigatus culture filtrate fractions in ELISA for the serological diagnosis of allergic aspergillosis. Mykosen 1984;27:327-39.

18 Kostiala AAI, Kostiala I. Enzyme-linked immunosorbent assay (ELISA) for IgM, IgG and IgA class antibodies against Candida albicans antigens: development and comparison with other methods. Sabouraudia 1981;19:123-34.

19 Kauffman HF, Beaumont F, Meurs H, van der Heide S, de Vries K. Comparison of antibody measurements against Aspergillus fumigatus by means of double-diffusion and enzyme-linked immunosorbent assay (ELISA). J Allergy Clin Immunol 1983;72:255-61.

20 Kauffman HF, van der Heide S, Beaumont F, et al. Class-specific antibody determination against Aspergillus fumigatus by means of the enzyme-linked immunosorbent assay. III. Comparative study: IgG, IgA, IgM ELISA titres, precipitating antibodies and $\mathrm{IgE}$ binding after fractionation of the antigen. Int Arch Allergy Appl Immunol 1986;80:300-6.

21 Harvey C, Longbottom JL. Development of a sandwich ELISA to detect IgG and IgG sub-class antibodies specific for a major antigen (Ag7) of Aspergillus fumigatus. Clin Allergy 1986;16:323-30.

22 Hearn VM, Proctor AG, Mackenzie DWR. The preparation and partial characterisation of antigenic fractions obtained from the mycelial walls of several Aspergillus species. J Gen Microbiol 1980;119:41-9.

$23 \mathrm{Kim}$ SJ, Chaparas SD, Brown TM, Anderson MC. Characterisation of antigens from Aspergillus fumigatus. II. Fractionation and electrophoretic, immunologic and biologic activity. Am Rev Respir Dis 1978;118:553-60.

Requests for reprints to: Dr J Froudist, Medical Mycology Laboratory, Combined Microbiology Services, State Health Laboratories, GPO Box F312 Perth, Western Australia 6001. 